\begin{tabular}{|c|c|c|}
\hline & Int.J.Curr.Microbiol.App.Sci (2020) 9(1): 231-236 & \\
\hline & $\begin{array}{l}\text { International Journal of Current Microbiology and Applied Sciences } \\
\text { ISSN: 2319-7706 Volume } 9 \text { Number } \mathbf{1}(\mathbf{2 0 2 0 )} \\
\text { Journal homepage: http://www.ijcmas.com }\end{array}$ & $\Rightarrow 0$ \\
\hline $\begin{array}{l}\text { EXCELLENT } \\
\text { PUBLISHERS }\end{array}$ & & Whiw ijemas \\
\hline
\end{tabular}

\title{
Days to 50\% Tasselling, Silking and Yield as affected by Planting Pattern and Weed Management in Field Pea and Baby Corn Intercropping System
}

\author{
Pradeep Kumar ${ }^{1 *}$, J. P. Singh ${ }^{1}$ and Manraj Yadav ${ }^{2}$ \\ ${ }^{1}$ Department of Agronomy, Banaras Hindu University, Varanasi, Uttar Pradesh - 221005 , \\ India \\ ${ }^{2}$ Department of Agronomy, Anand Agricultural University, Anand, Gujarat -302018, India \\ *Corresponding author
}

\section{A B S T R A C T}

\begin{tabular}{|l|}
\hline Ke y w o r d s \\
Planting pattern, \\
taselling, silking, \\
Yield, Field pea, \\
Baby corn
\end{tabular}

A two year field experiment was conducted during the rabi season of 2010-11 and 201112 at Varanasi, Uttar Pradesh. To study the Effect of Planting pattern and Weed management in Baby corn (Zea mays L.) intercropped with Field pea (Pisum sativum L.). Result showed that days to $50 \%$ taselling of baby corn did not vary significantly due to planting pattern. Various weed management practices were effective to record significant variation in days to $50 \%$ taselling during the course of investigation. The various planting pattern did not exhibit any significant differences in days to $50 \%$ silking. Various weed management practiced brought about significant variation in days to $50 \%$ silking. Maximum days taken to achieve 50\% silking was recorded under weedy check, while post-emergence application of imazethapyr @ $50 \mathrm{~g} \mathrm{ha}^{-1}$ brought about significant reduction in days to $50 \%$ silking. There was not any significant variation in the cob yield as influenced by planting pattern. Maximum grain yield was recorded with sole planting of baby corn and minimum was recorded with paired row planting of baby corn. Maximum cob yield was recorded with the post-emergence application of imazethapyr @ $50 \mathrm{~g} \mathrm{ha}^{-1}$. Planting pattern exhibited significant variation in recording higher grain yield in field pea. Further perusal of the data revealed that higher grain yield of $14.32 \mathrm{q} \mathrm{ha}^{-1}$ was recorded under sole planting and application of imazethapyr @ $50 \mathrm{~g} \mathrm{ha}^{-1}$ recorded maximum grain yield of $12.00 \mathrm{q} \mathrm{ha}^{-1}$ of field pea.

\section{Introduction}

Among the cereals, maize (Zea mays L.) ranks third in total world production after wheat and rice and it is principle staple food in many countries, particularly in the tropics and subtropics. Maize is considered as the "Queen of Cereals" since its multiple uses as food, feed, fodder and fuel. Being a $\mathrm{C}_{4}$ plant, it is capable to utilize solar radiation more efficiently even at higher radiation intensity. One such vegetable is baby corn. The term Baby corn, commonly referred by the food industry, refers to the young corn of maize, harvested within 1-2 days of silk emergence. The sweet, succulent and delicious baby corn 
is medium plant type and provides green ears within 65-75 days after sowing (Thavaprakash et al., 2006). Field pea (Pisum Sativum L.), a native of South West Asia, is among the first crops cultivated by man. Wild field pea can still be found in Afghanistan, Iran and Ethiopia. It is an important rabi (cool) season pulse crop in the country, grown mainly for food along with its use as hay, green fodder and concentrates for vast cattle population as well. In India, it is cultivated in an area of about 0.78 million hectare area with annual production of 0.71 million tonne (DES, Department of Agriculture and Cooperation, 2010-2011).

Crop geometry is a cost effective technique that modifies the crop canopy structure and micro-climate, enhances crop competitiveness in weed suppression, improves the resource use efficiency and maximizes crop productivity.

Intercropping of baby corn with legumes like field pea in different planting system $(1: 1,2: 1$, $3: 1$ and 2:2 row proportion etc.) produces better produce in a short period without any adverse effect on growth, development and productivity of sole crop and it also helps in soil and water conservation with increasing soil fertility and benefit:cost ratio.

Weed competition is a serious limitation in field pea due to its slow initial growth resulting in huge yield loss to the extent of $65.8 \%$ under unweeded condition (Mishra, 2006).

\section{Materials and Methods}

The present experiment was conducted at the Agricultural Research Farm, Institute of Agricultural Sciences, Banaras Hindu University, Varanasi, Uttar Pradesh (India) during rabi season 2010-2011 and 2011-2012. The climate of this region is sub-humid climate being often subjected to extremes of weather conditions. The rainfall received during the crop growing season amounted to $22.1 \mathrm{~mm}$. The maximum rainfall of $7.2 \mathrm{~mm}$ was recorded during the week 14 (April, 0208), while minimum was $0.6 \mathrm{~mm}$ in week number 47 (November, 19-25), 2010.

During the main crop growing season maximum temperature was in the range of 35.0 to $14.2^{\circ} \mathrm{C}$ whereas minimum temperature was in the range of 19.0 to $4.8^{\circ} \mathrm{C}$. The temperature at the time of harvesting was $31.8^{\circ} \mathrm{C}$. The soil of the experimental plot was typical Indo-Gangetic alluvium (OrderInceptisols) which in general are deep, flat, well drained and moderately fertile.

The experiment was laid out in split plot design with three replications. Sixteen treatment consisted of four planting pattern viz. Field pea sole, Baby corn sole, Normal planting of baby corn + field pea (1:1), Paired row planting of baby corn + field pea $(2: 2)$ as main plot treatment and four weed control practices, viz. Weedy check, Hand weeding at 25 DAS, Pendimethalin @ $1.0 \mathrm{~kg} \mathrm{ha}^{-1}$ as preemergence Imazethapyr @ $50 \mathrm{~g}$ a.i. ha ${ }^{-1}$ as post-emergence were allocated to sub-plot treatments. The experimental plot size was $14.4 \mathrm{~m}^{2}$ having $4.0 \mathrm{~m}$ length and $3.6 \mathrm{~m}$ width. Treatments were separated by $1 \mathrm{~m}$ plot border. The same field was used in both the years. The baby corn cultivar 'Malviya makka-2' and field pea cultivar 'HUDP-15' (Malviya matar15) were sown. Seeds rate @ $35 \mathrm{~kg} \mathrm{ha}^{-1}$ were used for sowing of baby corn. Seeds were sown by opening furrow at $40 \mathrm{~cm} \times 20 \mathrm{~cm}$ at normal row spacing while paired row spacing was $30 \mathrm{~cm}$ x $20 \mathrm{~cm}$. Seed rate @ $80 \mathrm{~kg} \mathrm{ha}^{-1}$ was used for field pea. It was sown in furrow opened by kudali. The recommended doses of NPK to baby corn was $90 \mathrm{~kg} \mathrm{~N}+40 \mathrm{~kg} \mathrm{P}_{2} \mathrm{O}_{5}+$ $40 \mathrm{~kg} \mathrm{~K}{ }_{2} \mathrm{O}$, whereas to field pea, it was $20 \mathrm{~kg}$ $\mathrm{N}+40 \mathrm{~kg} \mathrm{P}_{2} \mathrm{O}_{5}+60 \mathrm{~kg} \mathrm{~K}_{2} \mathrm{O} /$ ha. Full recommended dose of $\mathrm{P}$ and $\mathrm{K}$ along with half 
dose of $\mathrm{N}$ was applied as basal to both the crops in sole as well as intercropping system. Result half dose was top dressed at 30 DAS. The required quantity of herbicide was calculated as per the treatment. Pre-sowing irrigation was given 3 days before the land preparation.

Land was prepared to a good tilth and levelled uniformly before sowing. Ploughing was done with tractor drawn disc plough followed by harrowing in criss-cross manner. Finally the field was planked and levelled. Thereafter, layout was done as per pre-decided plan of experimental design.

\section{Days to $50 \%$ taselling}

Five plants were randomly selected in the net plot area and tagged and days of full emergence of tassels were recorded separately. The number of days when 5 tassels out of the 10 emerged fully was recorded.

\section{Days to 50\% Silking}

Five plants were randomly selected in the net plot area and tagged and days of emergence of silk of $50 \%$ of plants were recorded.

\section{Yield}

The baby cob and baby corn yield obtained as first and subsequent cobs were summed for total yield separately and presented in $\mathrm{q} \mathrm{ha}^{-1}$. In field pea grain yield of net plot after threshing, cleaning and drying was recorded in $\mathrm{kg}$ and converted to $\mathrm{q} \mathrm{ha}^{-1}$.

The data statistical analysis using "Analysis of variance technique, The differences between the treatment means were tested against critical difference (CD) at 5\% probability level where ever ' $F$ ' test was significant. However the data on weed population were analysed after making the square root $\sqrt{\mathrm{x}+0.5}$ transformation as suggested by Rangaswamy (1995).

\section{Results and Discussion}

The effect of various planting pattern and weed management practices on days to $\mathbf{5 0 \%}$ taselling

Days to $50 \%$ taselling of baby corn did not vary significantly due to planting pattern during the course of investigation (Table-1). It is obvious from the table that the maximum duration taken for days to $50 \%$ flowering was observed with sole baby corn while minimum duration taken for days to $50 \%$ flowering was observed with normal planting of baby corn + field pea. Maximum duration for days to $50 \%$ taselling was observed under weedy check while minimum duration recorded for days to $50 \%$ taselling was with the post-emergence application of imazethapyr @ $50 \mathrm{~g} \mathrm{ha}^{-1}$. Preemergence application of pendimethalin @ 1.0 $\mathrm{kg} \mathrm{ha}{ }^{-1}$ remained comparable to postemergence application of imazethapyr @ $50 \mathrm{~g}$ $\mathrm{ha}^{-1}$.

The effect of various planting pattern and weed management practices on days to 50\% Silking

It is obvious from the data (Table 1) that various planting pattern did not exhibit any significant differences in days to $50 \%$ silking. However, maximum duration taken for days to $50 \%$ silking was observed with sole planting of baby corn, while normal planting of baby corn recorded minimum days for $50 \%$ silking. Further investigation of the data (Table 1) revealed that various weed management practiced brought about significant variation in days to $50 \%$ silking. Maximum days taken to achieve $50 \%$ silking was recorded under weedy check, while post-emergence application of imazethapyr @ $50 \mathrm{~g} \mathrm{ha}^{-1}$ brought about significant reduction in days to 
50\% silking. Application of imazethapyr @ 50 $\mathrm{g} \mathrm{ha}{ }^{-1}$ remained at par to pre-emergence application of pendimethalin @ $1.0 \mathrm{~kg} \mathrm{ha}^{-1}$ which recorded non-significantly less number of days to $50 \%$ silking.

The effect of various planting pattern and weed management practices on Yield

Data pertaining to cob yield during the course of experimentation as influenced by various planting pattern and weed management practices are presented in Table 2. It is clear from the data that there was not any significant variation in the cob yield as influenced by planting pattern during the course of study (Table 2). Maximum grain yield (18.99 $\left.\mathrm{q} \mathrm{ha}^{-1}\right)$ was recorded with sole planting of baby corn and minimum (14.59 q $\mathrm{ha}^{-1)}$ was recorded with paired row planting of baby corn. Sole planting recorded the higher yield due to better availability of resources (Paulpandi et al., 1998). Further analysis of the data reveals that all the weed management practices were significantly superior to weedy check in respect of cob yield. Maximum cob yield was recorded with the post-emergence application of imazethapyr@50 $\mathrm{g} \mathrm{ha}^{-1}$ and it was statistically at par with pre-emergence application of pendimethalin @ $1.0 \mathrm{~kg} \mathrm{ha}^{-1}$.

However, minimum cob yield was obtained under weedy check treatment. Planting pattern exhibited significant variation in recording higher grain yield. Further perusal of the data revealed that higher grain yield of $14.32 \mathrm{q} \mathrm{ha}^{-1}$ was recorded under sole planting of field pea. Normal and paired row planting pattern proved to be significantly inferior to sole planting in respect of grain yield. Data on grain yield indicated significant variation due to different weed control practices.

Table.1 Days to 50\% taselling and $50 \%$ silking of baby corn as influenced by baby corn + field pea intercropping and weed management (pooled data of two years)

\begin{tabular}{|c|c|c|}
\hline Treatment & $\begin{array}{l}\text { Days to } 50 \% \\
\text { taselling }\end{array}$ & Days to $50 \%$ silking \\
\hline \multicolumn{3}{|c|}{ Planting pattern } \\
\hline Baby corn sole & 93.91 & 106.46 \\
\hline Normal planting (1:1) & 92.94 & 105.25 \\
\hline Paired row planting (2:2) & 93.32 & 105.78 \\
\hline $\mathbf{S E m} \pm$ & 0.49 & 0.41 \\
\hline $\mathrm{CD}(\mathbf{P}=\mathbf{0 . 0 5})$ & NS & NS \\
\hline \multicolumn{3}{|c|}{ Weed management } \\
\hline Weedy check & 96.21 & 108.03 \\
\hline Hand Weeding at 25 DAS & 94.12 & 106.78 \\
\hline Pendimethalin@1.0 kg a.i. ha ${ }^{-1}$ & 91.98 & 104.72 \\
\hline $\begin{array}{c}{\text { Imazethapyr } 50 \mathrm{~g} \text { a.i. ha }}^{-1} \text { at } 25 \\
\text { DAS }\end{array}$ & 91.23 & 103.78 \\
\hline $\mathrm{SEm} \pm$ & 0.49 & 0.39 \\
\hline $\mathrm{CD}(\mathrm{P}=\mathbf{0 . 0 5})$ & 1.45 & 1.16 \\
\hline
\end{tabular}


Table.2 Yield of baby corn as influenced by baby corn + field pea intercropping and weed management (pooled data of two years)

\begin{tabular}{|c|c|c|}
\hline Treatment & Baby corn yield $\left(\mathrm{q} \mathrm{ha}^{-1}\right)$ & Grain yield (q ha $\left.{ }^{-1}\right)$ \\
\hline \multicolumn{3}{|c|}{ Planting pattern } \\
\hline Field pea sole & - & 14.32 \\
\hline Baby corn sole & 18.99 & - \\
\hline Normal planting (1:1) & 18.14 & 10.13 \\
\hline $\begin{array}{l}\text { Paired row planting } \\
(2: 2)\end{array}$ & 14.59 & 10.04 \\
\hline SEm \pm & 0.47 & 0.26 \\
\hline $\mathrm{CD}(\mathrm{P}=\mathbf{0 . 0 5})$ & 1.83 & 1.01 \\
\hline \multicolumn{3}{|c|}{ Weed management } \\
\hline Weedy check & 15.80 & 10.77 \\
\hline $\begin{array}{c}\text { Hand weeding at } 25 \\
\text { DAS }\end{array}$ & 17.36 & 11.52 \\
\hline $\begin{array}{c}\text { Pendimethalin @ } 1.0 \\
\text { kg a.i. ha }^{-1}\end{array}$ & 17.37 & 11.70 \\
\hline $\begin{array}{l}\text { Imazethapyr } 50 \mathrm{~g} \text { a.i. } \\
\text { ha }^{-1} \text { at } 25 \text { DAS }\end{array}$ & 18.43 & 12.00 \\
\hline SEm \pm & 0.44 & 0.20 \\
\hline $\mathrm{CD}(\mathrm{P}=\mathbf{0 . 0 5})$ & 1.30 & 0.60 \\
\hline
\end{tabular}

All the weed management practices recorded higher grain yield significantly over control which had the lowest grain yield. Further, data revealed that application of imazethapyr @ 50 $\mathrm{g} \mathrm{ha}^{-1}$ recorded maximum grain yield of 12.00 $\mathrm{q} \mathrm{ha}^{-1}$. Pre-emergence application of pendimethalin @ $1.0 \quad \mathrm{~kg} \mathrm{ha}^{-1}$ remained statistically at par with hand weeding at 25 DAS in producing significant grain yield. Sole planting recorded the higher yield due to better availability of resources. This confirms the findings of Rani et al., (2011). Weed management practices did brought about a marked variation in the yield attributes of baby corn.

There was significant variation in the yield of baby corn due to application of imazethapyr as application of herbicide reduced the density and dry matter of weeds, due to this competition for resources was reduced resulting in increased yield of baby corn.
References

Directorate of Economics and Statistics, Department of Agriculture and Cooperation. 2011-12.

Mishra JS. 2006. Efficacy of post emergence herbicides against wild oat in field pea. Indian Journal of Weed Science.38: 140-142.

Paulpandi, V.K., Palaniappan, S.P. and Solaiappan, V., 1998, Effect of cycocel on different crop geometry and nutrient levels in sorghum (Sorghum bicolor). Indian Journal of Agronomy. 43: 524-527.

Rangaswamy. R. 1995. A text book of Agricultural Statistics. New Age International Publishers. pp. 389-412.

Thavaprakash, N., K. Velayudham and V.B. Muthukumar, 2006. Baby Corn. Agro Tech Publishers, Udaipur, India.

Rani, B.S., Sagar, G.K., Reddy, G.P. 2011. 
Effect of integrated weed management economics of sweet corn. Crop practices on growth, yield and Research.42(1/2/3): 87- 89.

\section{How to cite this article:}

Pradeep Kumar, J. P. Singh and Manraj Yadav. 2020. Days to 50\% Tasselling, Silking and Yield as affected by Planting Pattern and Weed Management in Field Pea and Baby Corn Intercropping System. Int.J.Curr.Microbiol.App.Sci. 9(01): 231-236. doi: https://doi.org/10.20546/ijcmas.2020.901.026 